\title{
Publisher Correction: Methylation deficiency disrupts biological rhythms from bacteria to humans
}

Jean-Michel Fustin (1), Shiqi Ye, Christin Rakers (1), Kensuke Kaneko, Kazuki Fukumoto, Mayu Yamano, Marijke Versteven, Ellen Grünewald, Samantha J. Cargill, T. Katherine Tamai@D, Yao Xu, Maria Luísa Jabbur, Rika Kojima, Melisa L. Lamberti, Kumiko Yoshioka-Kobayashi, David Whitmore @D, Stephanie Tammam, P. Lynne Howell (D), Ryoichiro Kageyama, Takuya Matsuo, Ralf Stanewsky (D), Diego A. Golombek, Carl Hirschie Johnson, Hideaki Kakeya (1), Gerben van Ooijen (10) \& Hitoshi Okamura

Correction to: Communications Biology https://doi.org/10.1038/s42003-020-0942-0, published online 06 May 2020.

The original version of this Article contained an error in the author affiliations.

Affiliation 17 incorrectly read 'Present address: Kyoto University, Graduate School of Medicine, Department of Neuroscience, Division of Physiology and Neurobiology, Yoshida-Konoe-cho, Oxford Road, Sakyo-ku, Kyoto 606-8501, Japan.’

This has now been corrected in both the PDF and HTML versions of the Article.

Published online: 04 June 2020

\footnotetext{
(c) (i) Open Access This article is licensed under a Creative Commons Attribution 4.0 International License, which permits use, sharing, adaptation, distribution and reproduction in any medium or format, as long as you give appropriate credit to the original author(s) and the source, provide a link to the Creative Commons license, and indicate if changes were made. The images or other third party material in this article are included in the article's Creative Commons license, unless indicated otherwise in a credit line to the material. If material is not included in the article's Creative Commons license and your intended use is not permitted by statutory regulation or exceeds the permitted use, you will need to obtain permission directly from the copyright holder. To view a copy of this license, visit http://creativecommons.org/licenses/by/4.0/.
}

() The Author(s) 2020 